\title{
Hinn íslenski fjármálastjóri: Einkenni, umhverfi og verkefni
}

\author{
Páll Ríkharðsson, Porlákur Karlsson og Catherine Batt ${ }^{1}$
}

\begin{abstract}
Ágrip
Pessi grein byggist á rannsókn sem var gerð árið 2008 og aftur árið 2014 m.a. á einkennum og verkefnaáherslum fjármálastjóra í 300 stærstu fyrirtækjum á Íslandi. Báðar rannsóknirnar náðu yfir $60 \%$ svörun sem pykir mjög gott meðal stjórnenda. Niðurstöður eru m.a. pær að íslenskir fjármálastjórar fylgja almennt sömu próun í áherslum og hlutverki og í öðrum löndum. Раð er að segja meiri áhersla er lögð á greiningar, ákvarðanatökustuðning og innanhúsráðgjöf en bókhald og uppgjör. Af öðrum niðurstöðum ber að nefna að fleiri konur eru fjármálastjórar í íslenskum fyrirtækjum en á Norðurlöndunum, rétt undir helmingur fjármálastjóra stærri fyrirtækja hefur verið ráðinn á síðustu 5 árum og skortur er á pekkingu á mörgum aðferðum og stöðlum stjórnunarreikningsskila og innra eftirlits (management accounting).
\end{abstract}

\begin{abstract}
This article is based on a research that was conducted in 2008 and 2014 focusing e.g. on the characteristics and roles of chief financial officers (CFO) of the 300 largest firms in Iceland. In both research a response rate of over $60 \%$ was achieved, which is quite good in management studies. The results showed that Icelandic CFOs in general are following a similar development in their task emphasis and roles as in other countries with more emphasis on analysis, support for decision making and internal advice than on bookkeeping and financial reporting. Other results show that proportionally more women are CFOs in Icelandic companies than in the other Nordic countries, little less than half of the CFOs of the largest firms have been hired in the last five years and there is a lack of knowledge among CFOs of several management accounting methods and frameworks.
\end{abstract}

JEL flokkun: M12

Lykilorð: Fjármálastjórar, stjórnunarreikningsskil, ICEMAC.

${ }^{1}$ Páll Ríkharðsson er dósent við viðskiptadeild Háskólans í Reykjavík. Porlákur Karlsson er dósent við viðskiptadeild Háskólans í Reykjavík. Catherine E. Batt er rannsóknarmaður við viðskiptadeild Háskólans í Reykjavík 


\section{Inngangur}

Erlendis hafa stjórnendahlutverk og áherslur fjármálastjóra verið rannsökuð (Canace og Juras, 2014; Edwards og Broyns, 2013; Ewert og Wagenhofer, 2007; Fleischman og Tyson, 2007; Näsi og Rohde, 2007). Pessar rannsóknir sýna m.a. að fjármálstjórinn er ekki lengur eingöngu bókari heldur inniheldur hlutverkið í dag m.a. hönnun upplýsingaferla, umsjón með upplýsingakerfum, pátttöku í stefnumótun, ákvörðunartökustuðning og ráðgjöf til annarra stjórnenda félagsins, upplýsingagjöf til ytri aðila og greiningar á upplýsingum. Einnig hafa erlendar rannsóknir sýnt að áherslur breytast í stjórnunarreikningsskilum² pegar ytra umhverfi fyrirtækja breytist, sérstaklega ef pað eru umbreytingar og óvissa í starfsumhverfi fyrirtækisins (Chenhall, 2003; Grabner og Moers, 2013; Malmi og Brown, 2008). Рó að fræðimenn séu almennt sammála um að breytingar í y tra umhverfi fyrirtækja leiði til breytinga á aðkomu stjórnenda að t.d. áætlanagerð og árangursstjórnun eru peir ekki sammála um hvaða breytingar eigi sér nákvæmlega stað (Ekholm og Wallin, 2011; Malmi og Brown 2008).

Engar rannsóknir hafa verið gerðar hingað til á hlutverki og áherslum íslenskra fjármálastjóra eða mati peirra á ytra umhverfi, óvissu og hugsanlegum tengslum við notkun á aðferðum stjórnunarreikningsskila. Fyrir íslenska fræðimenn á pessu sviði er mikilvægt að skilja hvort sama próun eigi sér stað í íslenskum fyrirtækjum og erlendum til pess m.a. að geta brugðist við með tilliti til áherslna í menntun verðandi fjármálastjóra í háskólum. Einnig hvort pað séu einhverjar séríslenskar aðstæður sem gera próunina öðruvísi hér á landi og pá af hverju. Fyrir íslenska fjármálastjóra er áhugavert að fá samanburð við erlendar rannsóknir og fá aðgang að gögnum sem lýsa starfsumhverfi og áherslum í mikilvægri en lítt rannsakaðri stjórnunarstöðu á Íslandi.

Tilgangurinn með pessari grein er pví að leita svara við premur spurningum:

1. Hvað einkennir fjármálastjóra í íslenskum fyrirtækjum?

2. Hvaða pættir í umhverfi fyrirtækja hafa mest áhrif á starf og hlutverk íslenskra fjármálastjóra?

3. Hafa orðið breytingar á áherslum og viðfangsefni stjórnunarreikningsskila íslenskra fjármálastjóra frá árinu 2008?

Svörin við pessum spurningum koma frá tveimur könnunum sem gerðar voru árið 2008 og 2014 og kallast ICEMAC 1 og 2, en báðar hlutu styrk frá RANNÍS. Í næsta kafla verður fjallað um aðferðafræði rannsóknanna, parnæst litið yfir niðurstöður erlendra rannsókna á próun í hlutverki og áherslum fjármálastjóra, í 4. kafla er niðurstöðum íslensku rannsóknarinnar lýst og pær túlkaðar og síðasti hlutinn inniheldur svo lokaorð og yfirlit yfir meginniðurstöður m.t.t. spurninganna priggja að ofan.

Markhópurinn fyrir pessa grein eru annarsvegar fræðimenn á sviði fjármálastjórnunar á Íslandi og hins vegar fjármálastjórar í íslenskum fyrirtækjum og stofnunum.

2 Management accounting á ensku, internt regnskab/økonomistyring á dönsku og interne Unternehmensrechnung/controlling á pýsku. 


\section{Aðferðafræði}

Sumrin 2008 og 2014 voru netkannanir lagðar fyrir stjórnendur 300 stærstu fyrirtækja á Íslandi, skv. lista Frjálsrar verslunar fyrir árið 2008 og 2013 (Heimur - Frjáls verslun, 2008; 2014).

ICEMAC 2 könnunin stóð yfir frá 4. júní til 31. ágúst 2014. Byrjað var á að hringja í fyrirtækin 300 til að komast að pví hver væri fjármálastjóri eða í hliðstæðri stöðu. Næst var rætt við hann, könnunin kynnt og síðan var viðkomandi beðinn um að taka pátt í henni. Peir sem sampykktu pátttöku fengu örfáum dögum síðar tölvupóst með slóð á könnunina sem peir smelltu á og svöruðu spurningunum. Pannig var á næstu vikum smám saman hringt í öll fyrirtækin og stjórnendur peirra sem sampykktu pátttöku fengu slóð á könnunina. Pá var ítrekun um pátttöku send allt að fjórum sinnum til peirra sem höfðu sampykkt að svara en höfðu ekki svarað. Að lokum var hringt seinni partinn í ágúst í allmarga í peim hópi sem ekki hafði svarað til að tryggja hátt svarhlutfall.

Af 300 stjórnendum, sem voru í úrtakinu 2014, neituðu 9 að taka pátt í könnuninni (3,0\%), pað náðist ekki í 45 (15,0\%), 55 lofuðu að svara en svöruðu svo ekki (18,3\%) og 191 svaraði (63,7\%). Pessi svörun upp á tæplega 64\% telst mjög há par sem um er að ræða suma af æðstu stjórnendum stærstu fyrirtækja á Íslandi. Pó er pað athyglisvert, að pví meiri sem velta fyrirtækjanna var peim mun líklegri voru stjórnendur til að svara, pannig að um prír af hverjum fjórum stjórnendum stórra fyrirtækja á Íslandi tóku pátt í könnuninni, en tæplega helmingur lítilla fyrirtækja (stærðarflokkun skv. flokkun Evrópusambandsins (European Commission, 2005)). Á hinn bóginn var svörun óháð starfsmannafjölda og kyni stjórnanda.

Um 78\% svarenda voru fjármálastjórar, en framkvæmdastjórar fyrirtækja svöruðu í um $10 \%$ tilvika og svo voru um $12 \%$ svarenda með ýmsa aðra titla stjórnenda. Af svarendum voru konur ríflega $38 \%$ og karlar tæplega $62 \%$.

Aðferðin í rannsókninni árið 2008 (ICEMAC 1) var mjög svipuð pessari rannsókn - úrtakið var fjármálastjórar eða peir sem ábyrgð bera á fjármáladeildum 300 stærstu fyrirtækja á Íslandi, aðferð við að safna svörum hin sama og svarhlutfall einnig mjög hátt (69\%). Nánar má lesa um aðferðafræðina í ICEMAC 1 í Rikhardsson, Karlsson, Sigurjonsdottir og Hilmarsson (2012). Meginmunurinn á aðferðafræði ICEMAC 1 og 2 var að í ICEMAC 1 var gerð forkönnun meðal valinna fjármálastjóra til að undirbúa sem bestan spurningalista. Sú forkönnun gaf m.a. pá pætti sem spurt var um m.t.t. áhrifa á starfsemi fjármáladeildar næstu árin (sjá viðauka).

Í báðum könnunum voru yfir 120 spurningar í 7 flokkum. Pær snerust um fjölmarga pætti í stjórnunarreikningsskilum og stjórnarháttum fyrirtækja, svo sem kostnaðargreiningu, áætlanagerð, innra eftirlit og áhættumat, árangursmælingar og árangursstjórnun. Tafla 1 gefur yfirlit yfir spurningaflokkana. Pessar rannsóknir stefndu að pví að afla gagna til að lýsa stöðu stjórnunarreikningsskila á Íslandi sem og komast pví hvort einhverjar breytingar hefðu átt sér stað milli áranna 2008 og 2014. Pessi grein byggist að mestu á svörum við spurningum í 1. og 7. flokki. Pær spurningar sem pessi rannsókn byggist á eru sýndar í viðauka. 
Tafla 1. Yfirlit yfir spurningar ICEMAC 1 og 2

\begin{tabular}{ll} 
Flokkar spurninga & Innihald \\
\hline 1. Bakgrunnsbreytur & $\begin{array}{l}\text { Spurningar um t.d. veltu, atvinnugrein, fjölda } \\
\text { starfsmanna og áhrif ytri breyta á starf } \\
\text { fjármálastjóra. }\end{array}$ \\
\hline 2. Kostnaðargreiningar & $\begin{array}{l}\text { Notkun á kostnaðargreiningarkerfum, pörf fyrir } \\
\text { úthlutun á kostnaði, notkun á verkgrunduðum } \\
\text { kostnaðarreikningum og hlutfall óbeins kostnaðar } \\
\text { af heildarkostnaði. }\end{array}$ \\
\hline 3. Áætlanagerð & $\begin{array}{l}\text { Notkun mismunandi áætlana, áætlunargerðarferli, } \\
\text { innihald áætlana, mikilvægi áætlana og eftirfylgni. }\end{array}$ \\
\hline 4. Innra eftirlit & $\begin{array}{l}\text { Spurningar um notkun ramma fyrir eftirlitskerfi, } \\
\text { áhættumat og stjórnarhætti. }\end{array}$ \\
\hline 5. Árangursmælikvarðar & $\begin{array}{l}\text { Notkun á árangursmælikvörðum eins og } \\
\text { stefnumiðuðu skorkorti og stefnukortum sem og } \\
\text { mælikvörðum sem eru ekki fjárhagslegir. }\end{array}$ \\
\hline 6. Upplýsingatækni & $\begin{array}{l}\text { Notkun á mismunandi upplýsingakerfum eins og } \\
\text { heildarkerfum (ERP kerfum), } \\
\text { viðskiptagreindarkerfum og greiningarkerfum. }\end{array}$ \\
\hline 7. Fjármálastjórinn og & $\begin{array}{l}\text { Spurningar um hlutverk og störf fjármálastjórans } \\
\text { og fjármáladeildarinnar. }\end{array}$ \\
\hline
\end{tabular}

Einnig var spurt í bæði ICEMAC 1 og 2 um pá pætti sem myndu hafa áhrif á próun fjármáladeildar næstu árin, ánægju stjórnenda með stjórnunarreikningsskilakerfi fyrirtækisins sem og líkur á að pessu kerfi yrði breytt næstu árin. Pessar spurningar eru einnig sýndar í viðauka.

Styrkleikar pessara rannsókna eru afar hátt svarhlutfall miðað við margar erlendar rannsóknir sem og margar spurningar sem fengist hefur svar við sem lýsa vel hlutverki og verkefnum fjármálastjóra í íslenskum fyrirtækjum. Ennfremur styrkir niðurstöður að hægt sé að gera samanburð milli ára. Takmarkanir eru pær sömu og í mörgum megindlegum rannsóknum par sem erfitt er að meta skilgreiningar svarenda á hugtökum sem og samræmi mats á spurningum sem krefjast túlkunar á t.d. afkomu og áhættu.

\section{Rannsóknir á umhverfi, einkennum, hlutverki og áherslum fjármálastjóra}

Í pessum kafla reifum við nokkrar rannsóknir sem fjalla um próun í starfi fjármálastjóra. Yfirferðin er sett upp í sömu röð og rannsóknarspurningarnar okkar. Рað er að segja: Hvað einkennir íslenska fjármálastjóra? Hvaða pættir í umhverfi fyrirtækja hafa mest áhrif á starf og hlutverk fjármálastjóra? Hafa orðið breytingar á áherslum og viðfangsefnum fjármálastjóra?

Við veljum að nota rannsóknir bæði ráðgjafafyrirtækja og fræðimanna. Ráðgjafafyrirtæki sem hafa rannsakað próun á hlutverki fjármálastjóra eru Boyden (alpjóðlegt ráðningarfyrirtæki), McKinsey and Company (alpjóðlegt ráðgjafafyrirtæki), EY (alpjóðlegt endurskoðunar- og ráðgjafafyrirtæki) og Deloitte (alpjóðlegt endurskoðunar- og ráðgjafafyrirtæki). Félagasamtök sem hafa rannsakað próun í áherslum og hlutverki fjármálastjóra eru ACCA (Association of Chartered Certified Accountants) sem eru samtök 
endurskoðenda í Englandi, IFAC (International Federation of Accountants), sem eru alpjóðleg samtök endurskoðenda og CIMA (Chartered Institute of Management Accountants) sem eru alpjóðleg samtök peirra sem vinna við stjórnunarreikningsskil. Rannsóknir ráðgjafafyrirtækja og félagasamtaka eru oft lýsandi (descriptive) en rannsóknir fræðimanna tengja niðurstöður við fræði og kenningar. Pær rannsóknir ráðgjafafyrirtækja og samtaka sem vitnað er í gefa m.a. upp fjölda viðmælenda, ferli við gagnaöflun, spurningar og tilgang rannsóknarinnar. Pannig er hægt að einhverju leyti að meta pá aðferðafræði sem beitt er.

\subsection{Hvað einkennir fjármálastjóra?}

Ráðgjafafyrirtækið Ernst \& Young lýsir í skýrslu sinni „The DNA of the CFO“, sem gefin var út árið 2010 og byggist á rannsókn sem náði til 699 fjármálastjóra, hinum dæmigerða fjármálastjóra sem 42 ára gömlum karli (Ernst \& Young, 2010). Pá birti Deloitte t.d. rannsókn árið 2011 sem sýnir að hlutfall kvenna í fjármálastjórastöðum er 10-20\% í flestum vestrænum ríkjum (Deloitte, 2011). Í nágrannalöndum Íslands virðist meirihluti fjármálastjóra vera karlar. Hlutfall kvenna í fjármálastjórastöðum á Norðurlöndunum var 13,9\% í Danmörku, 20,7\% í Noregi, 17,8\% í Svípjóð og 17,2\% í Finnlandi (CCD, 2009). Í Bandaríkjunum voru fjármálastjórar á hinn bóginn kvenkyns í 54 fyrirtækjum á S\&P 500 listanum árið 2013, eða í 10,8\% tilvika (Frier og Hymowitz, 2013).

Erlendar rannsóknir sýna að menntun og reynsla fjármálastjóra er margvísleg og ekki aðeins byggð á reikningshaldi og reikningsskilum (Boyden, 2014). Rannsókn á fjármálastjórnun nokkurra alpjóðlegra fyrirtækja sýndi að hæfnis- og menntunarkröfur til fjármálastjóra og starfsmanna fjármáladeilda innihalda pætti eins og t.d. upplýsingatækni, breytingastjórnun, stefnumótun, tjáningarhæfileika, leiðtogahæfileika, greiningarhæfileika og almenna stjórnunarmenntun (Boyden, 2014).

Til eru margar aðferðir, hugsanarammar og staðlar pegar kemur að stjórnunarreikningsskilum (CIMA, 2009). Fjármálastjórar pekkja sumar pessara aðferða betur en aðrar (CIMA, 2009; Nielsen, Melander og Jacobsen, 2003). Til dæmis virðast aðgerðatengd kostnaðargreining (ABC), stefnumiðað skorkort (balanced scorecard) og samfelld spá (rolling forecast) vera vel pekkt meðal fármálastjóra á meðan önnur eins og Business Excellence-líkanið, Kaizen costing og Life Cycle Costing virðast vera minna pekkt. Svo virðist sem fjármálastjórar í mismunandi löndum pekki sömu aðferðirnar, sem gæti bent til ákveðinnar stöðlunar í aðferðafræði stjórnunarreikningsskila eins og fræðimenn hafa bent á áður (Granlund og Lukka, 1998).

3.2 Hvaða pættir i umhverfi fyrirtækja hafa mest áhrif á starf og hlutverk fjármálastjóra? Breytingar í starfsumhverfi fjármálastjóra hafa áhrif á rekstur, kerfi og ferla fyrirtækisins og pær ákvarðanir sem par eru teknar (Chenhall, 2003). Ytra umhverfi fyrirtækja er til dæmis hægt að skipta í hegðun birgja, eftirspurn og neytendahegðun, alpjóðavæðingu og erlenda samkeppni, hegðun keppinauta, nýjar vörur frá keppinautum, nýja keppinauta, tæknilegar breytingar, lög og reglugerðir sem fyrirtækið verður að hlíta, fjárhagslegt umhverfi, tengsl milli fyrirtækja í atvinnugrein, próun á hráefnamörkuðum og próun á atvinnumarkaði (Ekholm og Wallin 2011; Houqe, 2004).

Pær rannsóknir sem gerðar hafa verið á hvað hefur áhrif á starfsumhverfi fjármálastjóra hafa notað m.a. mat fjármálastjóra á óvissustigi í umhverfinu eða svokallað perceived environmental uncertainty (PEU). Óvissa með tilliti til umhverfispátta tekur yfir ófyrirsjáanleika próunar, óvissu um hegðun annarra og óvissu um afleiðingar ákvarðana sem teknar eru (Hoque, 2004). Hoque (2004) komst að pví að fjármálastjórar í Ástralíu mátu mestu óvissuna í 
kringum alpjóðavæðingu (3,98), hegðun keppinauta $(3,63)$, neytendahegðun $(3,52)$ og tæknipróun (3,50) á kvarða frá 1 til 5 par sem 5 var hæsta óvissustig. Ekholm og Wallin (2011) mældu hvernig sænskir fjármálastjórar upplifðu óvissu með tilliti til 12 umhverfispátta. Stjórnendur merktu við á kvarða frá 1 til 7, par sem 7 var mikill ófyrirsjáanleiki í umhverfi fyrirtækis. Peir mátu mesta óvissu á hráefnamörkuðum (4,43), í alpjóðavæðingu (3,93), hegðun keppinauta $(3,89)$ og fjárhagslegu umhverfi $(3,82)$. Schulz o.fl. (2010) mældu ófyrirsjáanleika fjárhagslegs, tæknilegs og lagalegs umhverfis að mati stjórnenda 84 fyrirtækja í Taiwan. Mest óvissa pótti ríkja um fjárhagslegt umhverfi.

Rannsóknir af pessu tagi hafa verið gagnrýndar fyrir annarsvegar að nota mat stjórnenda á óvissu og hinsvegar að lýsa ekki breytingum með öðru en einni tölu - p.e.a.s. t.d. meðaltali á peim kvarða sem er notaður til að meta ófyrirsjáanleika umhverfispátta (Suarez og Olivia, 2005). Suarez og Olivia (2005) leggja til að breytingar í umhverfi fyrirtækja flokkist eftir styrkleika breytinga mælt í hversu oft breytingar gerast (tíðni, frequency), stærð miðað við upprunalegt ástand (frávik, amplitude), hraða breytinga (speed) og umfang (scope). Mismunandi samsetning af pessum breytum gefa fimm flokka af breytingarstigi: Regular, Hyperturbulence, Specific shock, Disruptive, Avalanche. Tafla 2 sýnir pessa flokkun breytinga í umhverfi fyrirtækja (Suarez og Olivia, 2005, bls. 1022).

Tafla 2. Flokkun á stærð og umfangi umhverfisbreytinga

\begin{tabular}{lllll} 
Tíðni & Frávik & Hraði & Umfang & Tegund \\
\hline Lág & Lítið & Lítill & Lítið & Regular \\
\hline Há & Lítið & Mikill & Lítið & Hyperturbulence \\
\hline Lág & Mikið & Mikill & Lítið & Specific Shock \\
\hline Lág & Mikið & Lítill & Lítið & Disruptive \\
\hline Lág & Mikið & Mikill & Mikið & Avalanche \\
\hline
\end{tabular}

Suarez og Olivia (2005) styðjast við tölfræði og hagupplýsingar til að sýna hvaða breytingar gerast og hversu hratt. Höfundar nota pessa flokkun til að lýsa breytingum á efnahagsástandi landa í Suður-Ameríku byggt á hagpróun í pessum löndum. Við munum nota pessa aðkomu til að lýsa peim breytingum sem gerðust í starfsumhverfi íslenskra fjármálastjóra seinna.

\subsection{Breytingar á hlutverkum og viðfangsefnum fjármálastjóra}

Erlendar rannsóknir fræðimanna, félagasamtaka og ráðgjafafyrirtækja sýna að hlutverk fjármálastjóra er að breytast (ACCA, 2012; Boyden, 2014; Canace og Juras, 2014; CIMA, 2010; IFAC, 2013). Áður fyrr var meginhlutverk fjármálastjóra skráning viðskiptaupplýsinga (bókhald), upplýsingagjöf til ytri aðila (reikningsskil), samstarf við ytri endurskoðanda, próun innra eftirlits og áhættustýring (Edwards og Broyns, 2013). Samkvæmt peim var litið á fjármálastjóra fyrst og fremst sem bókara og eftirlitsmann og pað var fremur sjaldgæft að sjá fjármálastjóra sem hluta af æðsta stjórnunarteymi eða sem hægri hönd framkvæmdastjóra. Próun í t.d. upplýsingatækni með tilkomu heildarkerfa og gagnagrunna sem og áherslur á viðskiptaferli færði fjármálastjóra meira í átt að uppbyggingu og tengingu viðskipta- og upplýsingaferla, sérstaklega par sem mörg heildarkerfi eru samtengd gegnum fjármálahluta pessara kerfa (Rikhardsson og Kraemmergaard, 2006). Í innleiðingu á árangursmælitækjum (t.d. stefnumiðuðu skorkorti og stefnukorti (strategy map)) fær fjármálastjórinn pað hlutverk 
að hanna og innleiða upplýsingaferla og vera pannig hönnuður að betri aðferðafræði og ferlum til stuðnings ákvarðanatöku í fyrirtækinu (Hope 2006; IFAC, 2013).

Kreppan 2008 kallaði á aðhaldsaðgerðir, áhættustýringu og eftirlit í mörgum fyrirtækjum (Stede, 2011). Fjármálastjórar voru pá oft í lykilhlutverki í pessum aðgerðum sem kallaði á aukna pátttöku í stefnumótun og markmiðasetningu og jók sýnileika fjármálastjórans (Stede, 2011). Á sama tíma hefur próun í upplýsingatækni haldið áfram að auka mikilvægi upplýsingagjafar beint til notandans, sveigjanlegri samtengd kerfi og mikilvægi greiningarvinnu fyrir nýjungar og stefnumótun (Davenport, 2010; Rikhardsson, 2013). Hlutverk fjármálastjórans er í dag fremur að skapa vitneskju, dreifa réttum upplýsingum til réttra notenda á réttu formi á réttum tíma, gefa ráð um greiningar, innleiðingar og ákvarðanir heldur en að vera bókari (ACCA, 2012; Canace og Juras, 2014; CIMA, 2010).

Pegar ofannefndar rannsóknir á hlutverki fjármálastjóra eru teknar saman koma nokkur mismunandi hlutverk fjármáladeilda og fjármálastjóra í ljós. Pau eru:

1. Bókhaldsfærslur og skráning upplýsinga: Bókhald og skráning upplýsinga, trygging upplýsingaöryggis sem og flokkun upplýsinga.

2. Upplýsingamiðlun til ytri aðila: Gerð ársreikninga, samvinna með endurskoðendum og miðlun ársreikninga og annarra upplýsinga til ytri aðila eins og hluthafa, eigenda, stofnana, lánveitenda o.s.frv.

3. Að styðja ákvarðanatöku annarra stjórnenda. Hönnun ferla og aðferða til stuðnings mismunandi ákvarðana.

4. Innri ráðgjöf í hönnun ferla, notkun aðferða, beiting upplýsingatækni og betri stjórnunarhátta.

5. Greining upplýsinga sem hluti af stuðningi við ákvarðanatöku eins og t.d. arðsemisgreiningar, tekjugreiningar, kostnaðargreiningar og frávikagreiningar.

6. Innra eftirlit: Tekur yfir vöktun á hlítingu við lög og reglur, skjölun á áhættu og eftirliti, hönnun og innleiðingu eftirlitsaðgerða, áhættumat og eftirfylgni.

Erlendu rannsóknirnar (ACCA, 2012; Canace og Juras, 2014; IFAC, 2013; CIMA, 2010; McKinsey \& Company, 2009) sýna að vægi stuðnings við ákvarðanatöku, ráðgjafar og greiningar hefur aukist á síðustu árum í hlutverki fjármálastjórans á meðan hlutfallslegt vægi bókhalds og upplýsingamiðlunar virðist minnka eða standa í stað.

Pegar litið er á meginviðfangsefni fjármálastjórans í stjórnunarreikningsskilum eru eftirfarandi mest áberandi samkvæmt kennslubókum og fræðigreinum (Atkinson, Kaplan og Young, 2011; Burchell, Clubb, Hopwood, Hughes og Nahapie, 1985; Näsi og Rohde, 2007):

1. Kostnaðargreiningar: Innifelur kostnaðarbókhald, arðsemisgreiningar, dreifingu óbeins/sameiginlegs kostnaðar á deildir, vörur eða viðskiptavini.

2. Áætlanagerð: Inniber gerð áætlanaforsenda, spálíkön, söfnun upplýsinga, framsetningu mismunandi tegunda áætlana, eftirfylgni og frávikagreiningu.

3. Árangursstjórnun: Innifelur mælingar á árangri, tengingu við markmið fyrirtækisins, hönnun og innleiðingu mælikvarða og uppsetningu árangursstjórnunaraðferða.

Margir fræðimenn hafa rannsakað hvernig ytra umhverfi fyrirtækisins próast (Chenhall, 2003, 2006; Ekholm og Wallin, 2011; Garengo og Bititci, 2007; Hoque, 2004). Rannsóknir peirra benda til að breytingar í umhverfi fyrirtækja leiði til breytinga í aðkomu fjármálastjóra að hönnun og beitingu aðferða sem og notkun upplýsinga m.t.t. kostnaðargreininga, 
áætlanagerðar og árangursstjórnunar. Chenhall (2003 og 2006) kemst að peirri niðurstöðu í yfirliti yfir rannsóknir á pessu sviði að eftir pví sem umhverfið verður óstöðugra og óvissan eykst peim mun meiri áherslu leggja stjórnendur á fjölbreyttari upplýsingar, sveigjanlegri áætlanagerð, notkun mælikvarða sem ekki eru fjárhagslegir og eftirlit með árangri fremur en aðgerðum og aðföngum. Nýrri rannsóknir benda pó til að breytingar á pessum kerfum séu flóknari par sem stjórnunarreikningsskilakerfi hanga saman í stærri einingum og erfitt sé að meta breytingar í öllu kerfinu út frá breytingum í einstökum páttum pess (Malmi og Brown, 2008). Pannig er erfitt út frá núverandi vitneskju að segja nákvæmlega hvernig t.d. áætlanagerð eða kostnaðarstýring breytist hjá tilteknu fyrirtæki pegar óvissustig eykst í umhverfinu (Malmi og Brown, 2008).

\section{Starfsumhverfi, einkenni, hlutverk og viðfangsefni íslenskra fjármálastjóra: Niðurstöður ICEMAC-rannsókna}

Hér eru kynntar niðurstöður rannsóknar okkar. Við byggjum pennan kafla upp eftir peim spurningum sem við spyrjum í upphafi greinar og lýsum fyrst niðurstöðum um einkenni fjármálastjóra í íslenskum fyrirtækjum, pá lýsum við áhrifum breytinga í starfsumhverfi fjármálastjóra og að lokum fjöllum við um niðurstöður rannsóknarinnar um breytingar í hlutverki og áherslum fjármálastjóra milli áranna 2008 og 2014. Tekið er fram í yfirferðinni ef marktækur munur var á svörum stórra og lítilla fyrirtækja, sem og milli atvinnugreina.

\subsection{Hver eru einkenni hins íslenska fjármálastjóra?}

Pegar litið er á hvað einkennir íslenska fjármálastjóra kemur í ljós að 38,2\% peirra í pví 191 fyrirtæki sem svör fengust frá eru konur. Af öllum 300 fyrirtækjunum í pýðinu er 101 kona fjármálastjóri eða 33,7\%. Petta er nokkuð hærra hlutfall en á hinum Norðurlöndunum sem kom fram í kafla 3.3 og mun hærra en í Bandaríkjunum. Pað má hins vegar oftar finna karl sem fjármálastjóra í stærri fyrirtækjum á Íslandi en peim smærri.

Fjármálastjórarnir voru einnig spurðir um menntun. Flestir peirra eru með háskólagráðu - annaðhvort grunngráðu (35\%) eða meistaragráðu (32\%) - en pó hafa sumir eingöngu stúdentspróf. Stærsti hópurinn er með meistarasérhæfingu í fjármálum fyrirtækja eða reikningshaldi og endurskoðun. Allnokkrir eru einnig með gömlu cand oecon gráðuna (21\%) en hætt var að útskrifa nemendur með hana árið 1996 (Sjá Gylfi Dalmann Aðalsteinsson og Póra Hrólfsdóttir, 2008, bls. 11). Um pað bil 37\% fjármálastjóra með cand oecon eru búnir að starfa í 10 ár eða lengur í núverandi stöðu. Konur í fjármálastjórastöðu eru oftar með 3ja ára háskólagráđu en karlar, en svarendur með 5 ára háskólagráðu eru jafnt karlar og konur. Fremur lítið hlutfall svarenda er löggiltir endurskoðendur. Eina marktæka sambandið á milli menntunar og annars bakgrunns er að peir sem eingöngu hafa stúdentspróf starfa fremur í litlum fyrirtækjum.

Pá voru fjármálastjórarnir spurðir hversu lengi peir hefðu verið í núverandi starfi (mynd 1). Af svörunum má lesa að pó nokkur starfsmannavelta var á fjármálastjórum stærri fyrirtækja fyrir 2-5 árum en um 43\% allra fjármálastjóra stærri fyrirtækja byrjuðu pá í starfi. Fjármálastjórar minni fyrirtækja virðast hafa enst betur í starfi almennt en fjármálastjórar stærri fyrirtækja. 


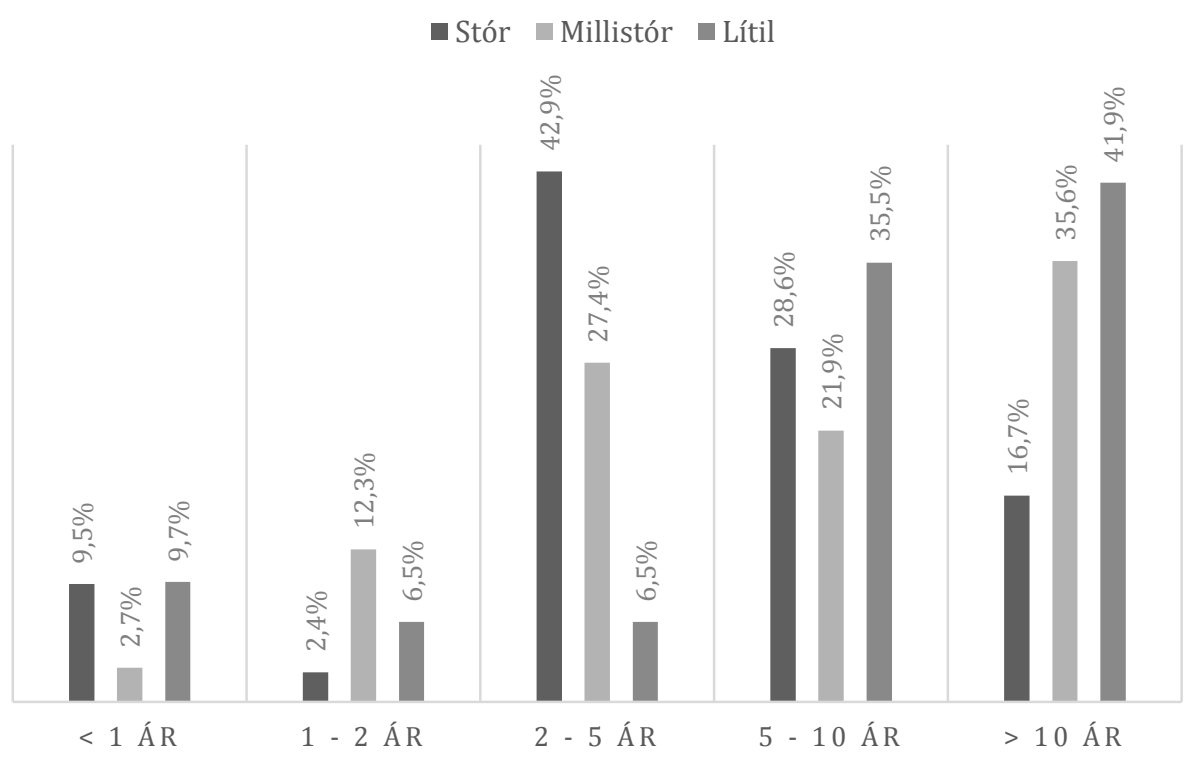

Mynd 1. Reynsla fjármálastjóra í núverandi starfi eftir stærð fyrirtækis.

Spurt var um pekkingu fjármálastjóra á hinum ýmsu aðferðum (methods), hugtakaramma (frameworks) og stöðlum (standards) í stjórnunarreikningsskilum og innra eftirliti. Pau voru valin út frá kennslubókum í stjórnunarreikningsskilum (Atkinson o.fl., 2011), innra eftirliti (Tarantino, 2011) og reikningsskilum (Kimmel, Weygandt og Kieso, 2011). Listinn yfir aðferðirnar og hugtakakerfin sem spurt var um er auðvitað ekki tæmandi. Niðurstöður sýna að pó nokkur munur var á hversu vel fjármálastjórar pekktu hinar ýmsu aðferðir og hugtök eins og sést á mynd 2. Innri eftirlitsaðferðirnar COCO, COBIT og COSO eru minnst pekktar meðal íslenskra fjármálastjóra. Pessar prjár eru pó oft nefndar t.d. í kennslubókum um innra eftirlit (Tarantino, 2011). Раð sést einnig að pekking á útbreiddum árangursstjórnunaraðferðum eins og strategy maps, Lean og Six Sigma aðferðafræðinni er fremur lítil. Pekking á hefðbundnum aðferðum eins og framlegðargreiningum, forecasting, full cost accounting og activity based costing virðist hinsvegar almennt vera til staðar. 


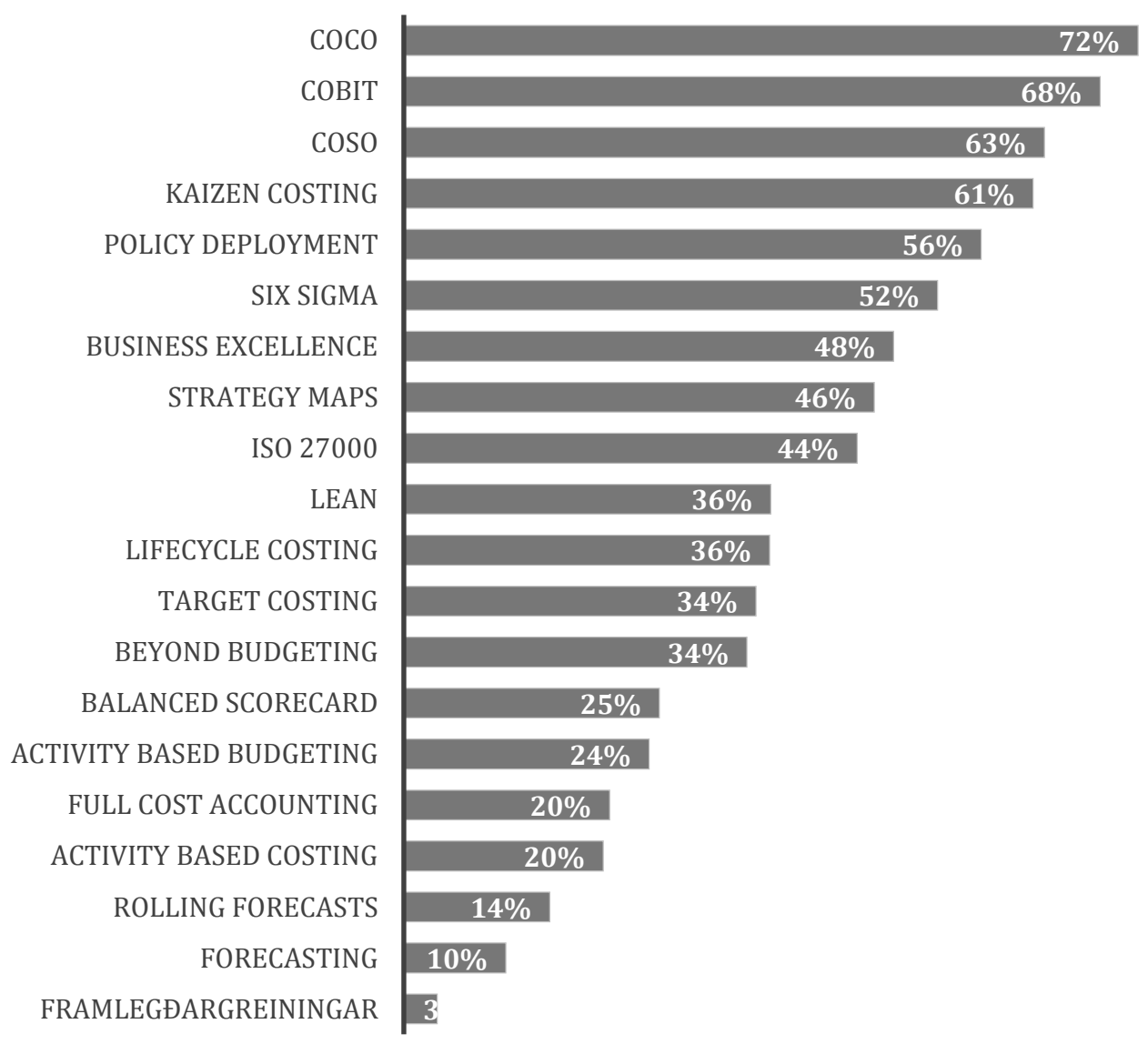

Mynd 2. Hlutfall svarenda sem pekkir ekki nefnda aðferð, hugtakaramma eða staðal.

Menntun og kyn fjármálastjóra og stærð fyrirtækja virðast ekki tengd pekkingu peirra á pessum aðferðum og stöðlum í stjórnunarreikningsskilum.

\subsection{Starfsumhverfi íslenskra fjármálastjóra 2008 - 2014}

Pegar litið er á flóru fyrirtækja á Íslandi kemur í ljós að árið 2013 mátti telja 64.625 skráð fyrirtæki og félög af ýmsum gerðum skv. Hagstofu Íslands (2013), p.á.m. 31.086 einkahlutafélög. Til samanburðar voru 57.525 fyrirtæki og félög skráð árið 2008. Árið 2014 eru 12 fyrirtæki skráð á hlutabréfamarkað, sem samsvarar 4\% af 300 stærstu fyrirtækjum landsins (sjá t.d. heimasíðu Kauphallarinnar www.nasdaqomxnordic.com). Heildarvelta fyrirtækja á Íslandi árið 2013 var 3.368 milljarðar kr. og verg landsframleiðsla 1.786 milljarðar kr. Heildarvelta 300 stærstu fyrirtækja árið 2013 var 2.968 milljarðar kr. eða 88\% af heildarveltu fyrirtækja á Íslandi sama ár (Heimur - Frjáls Verslun 2008; 2014).

Í ICEMAC 2-verkefninu var stuðst við eins og áður segir lista Frjálsrar verslunar yfir 300 stærstu fyrirtæki Íslands eftir veltu árið 2013 (Heimur - Frjáls verslun, 2014). Par sést að listinn spannar allt frá alpjóðlegum fyrirtækjum skráð á markað hérlendis og erlendis með púsundir starfsmanna til lítilla fjölskyldufyrirtækja. Fyrirtækin voru flokkuð eftir skilgreiningu ESB um stærð fyrirtækja (European Commission, 2005), sem sjá má á töflu 3. 
Tafla 3. Skilgreining á stærð fyrirtækja skv. ESB

\begin{tabular}{lll}
\hline Flokkur & Fjöldi starfsmanna & Velta \\
\hline Stór & $250-$ & $>€ 50$ milljónir \\
Millistæro & $50-249$ & $\leq € 50$ milljónir \\
Lítil & $11-49$ & $\leq € 10$ milljónir \\
Míkró & $1-10$ & $\leq € 2$ milljónir \\
\hline
\end{tabular}

Samkvæmt pessari flokkun má telja 67 stór fyrirtæki, 131 miðlungi stórt og 102 lítil fyrirtæki meðal 300 stærstu fyrirtækja á Íslandi árið 2013 (Heimur-Frjáls Verslun, 2014). Fjallað er um lítil fyrirtæki og míkró fyrirtæki sem einn stærðarflokk í pessari rannsókn. Hér á eftir munum við miða við stærð fyrirtækja í veltu og taka fram ef um er að ræða stærð eftir starfsmannafjölda.

Af pví 191 íslenska fyrirtæki sem tók pátt reka 65\% peirra fleiri en eina starfsstöð, annað hvort á Íslandi eða erlendis. Fjármálastjórar pessara fyrirtækja purfa pví að taka tillit til samhæfingar verkferla og hærra flækjustigs í t.d. uppsetningu kostnaðarstaða (cost centers). Um 12\% fyrirtækja eru hluti af erlendri samstæðu. Af pessum fyrirtækjum svöruðu $30 \%$ að vinnuferli fjármálastjórans m.t.t. stjórnunarreikningsskila væru sett upp alveg eða að hluta til eftir kröfum frá erlendu móðurfyrirtæki.

Próun í starfsumhverfi íslenskra fyrirtækja síðustu ár hefur öðru fremur einkennst af peim efnahagslegu breytingum sem fylgdu í kjölfarið á hruni bankanna 2008. Ef litið er t.d. á verga pjóðarframleiðslu (mynd 3) frá árunum 1995 til 2013 er samdrátturinn eftir 2008 sá stærsti frá 1995 (Hagstofa Íslands 2013). Aðrar hagtölur um t.d. atvinnuleysi, gjaldprot, skuldir heimila og stofnun nýrra fyrirtækja bera einnig vitni um pessar breytingar í umhverfi íslenskra fyrirtækja (Viðskiptaráð Íslands, 2014).

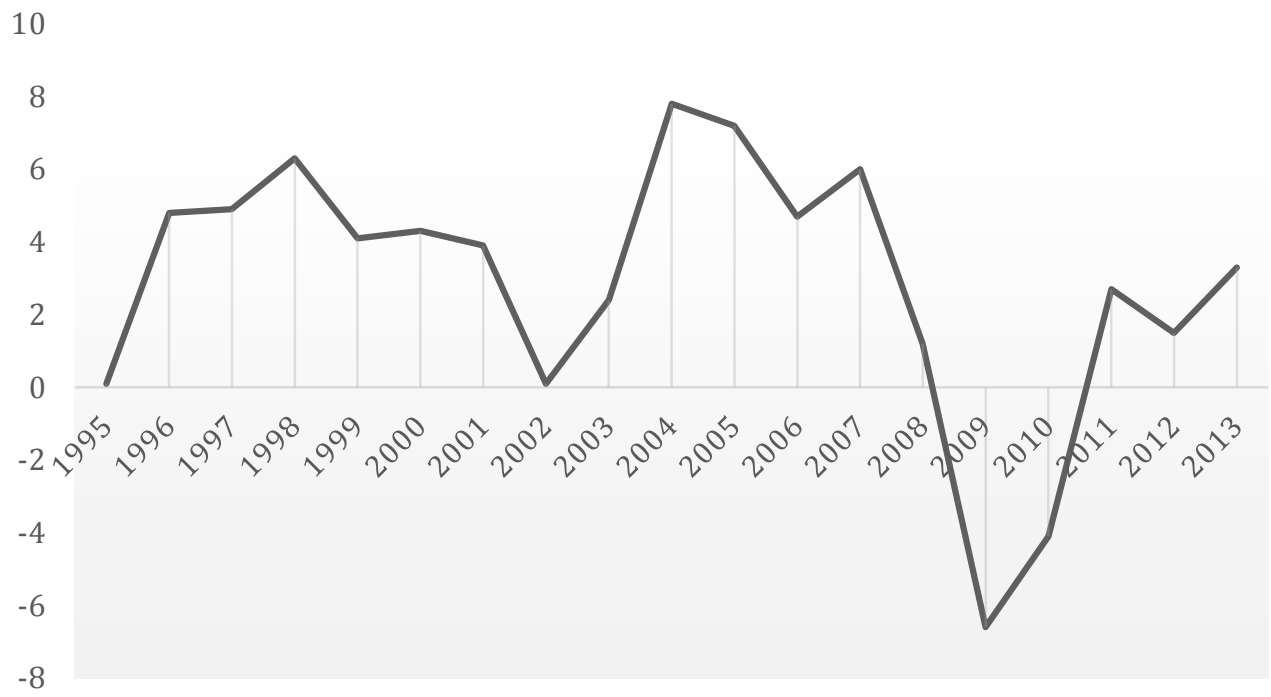

Mynd 3. Próun vergrar landsframleiðslu 1995 - 2013 (Hagstofa Íslands, 2014).

Á mynd 4 sést að velta 300 stærstu fyrirtækja á Íslandi prefaldaðist næstum á árunum 2002-2007. Starfsumhverfi fjármálastjóra á Íslandi fyrir 2008 hefur pví einkennst af pví að stjórna í örum vexti, á meðan starfsumhverfið eftir 2008 hefur einkennst af stöðnun, aðhaldsaðgerðum og minnkandi veltu. 


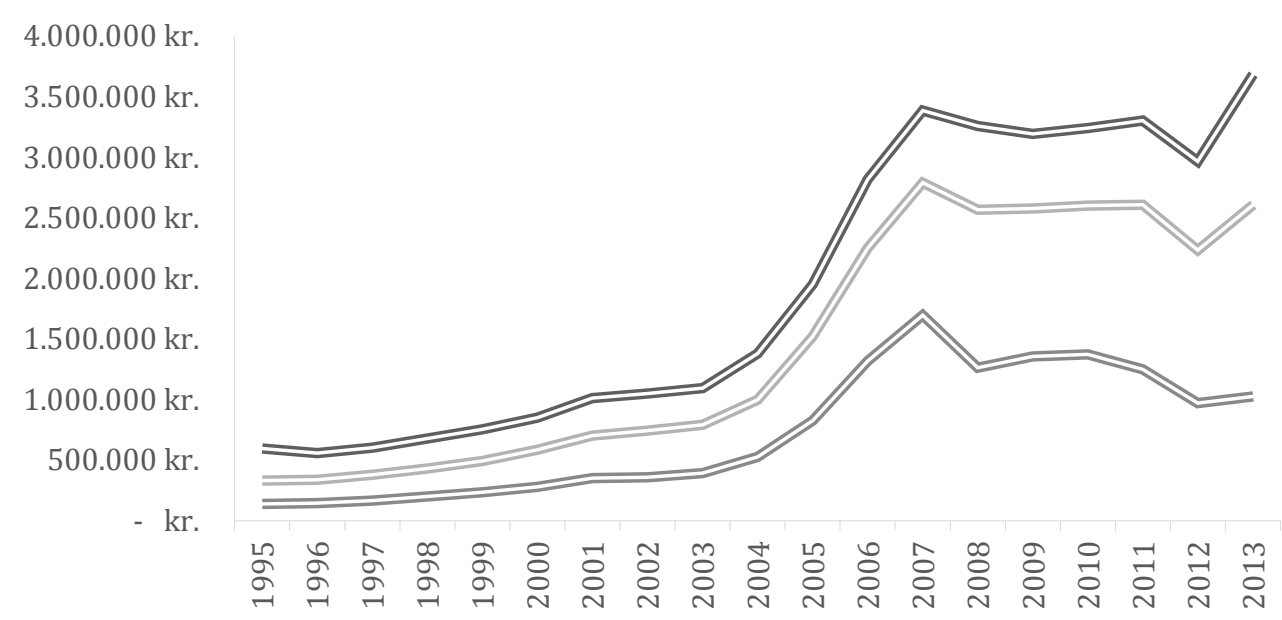

Mynd 4. Breytingar í veltu 300 stærstu fyrirtækja á Íslandi (Heimur - Frjáls Verslun 2013).

Ef pessar breytingar í starfsumhverfi íslenskra fjármálastjóra eru settar inn í hugmyndaramma Suarez og Olivia (2005) er hægt að flokka pessa breytingu í annaðhvort Specific shock eða Avalance breytingarstig. Рað er að segja, pessar breytingar gerast ekki oft, frávik frá fyrri stöðu eru mikil, hraði breytinga er mikill og umfangið er annað hvort lítið eða mikið allt eftir pví hvað breytingarnar taka til margra pátta í umhverfi fyrirtækisins. Flokkunarkerfið bendir pví til pess að breytingar í starfsumhverfi fjármálastjóra 2008 hafi verið umtalsverðar.

Í rannsókn okkar 2014 spurðum við íslenska fjármálastjóra um mat peirra á óvissustigi í umhverfi fyrirtækisins (perceived environmental uncertainty). Pessi spurning var ekki í 2008 rannsókninni. Við notuðum sömu skiptingu á umhverfispáttum og notaðir voru í grein Hoque (2004) og Ekholm og Wallin (2011). Petta er sýnt á mynd 5.

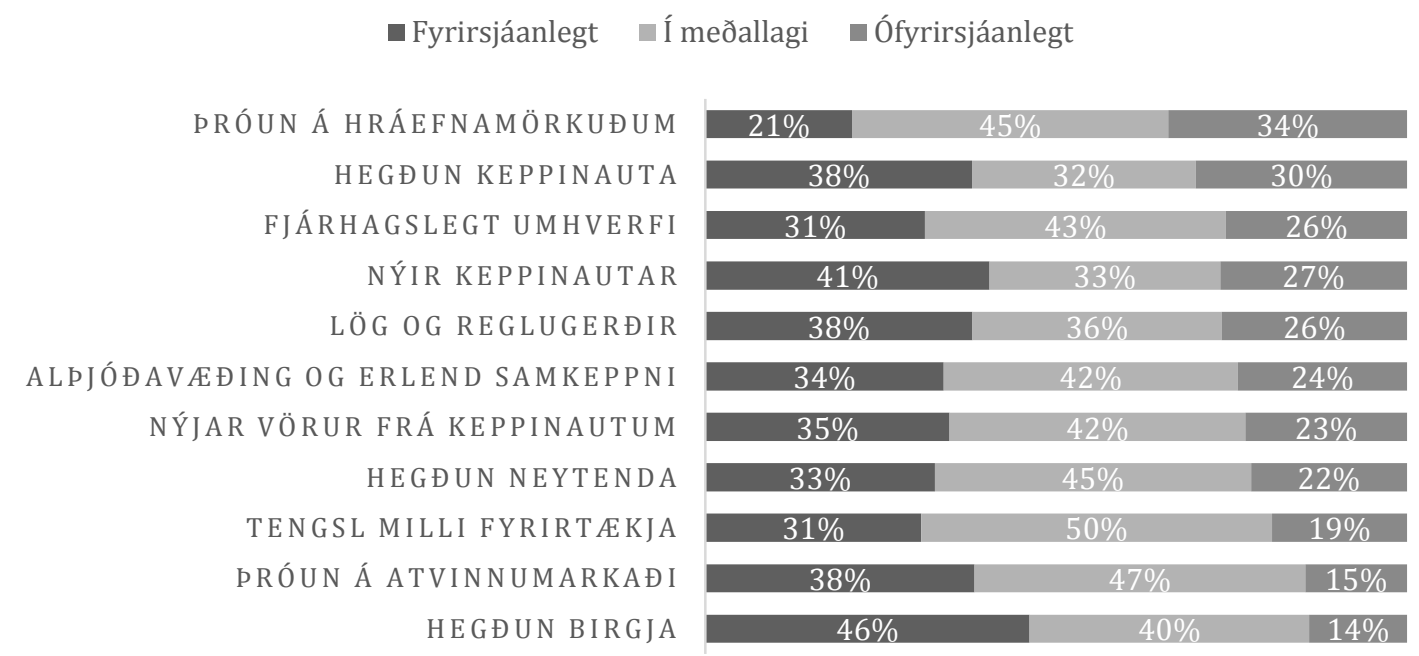

Mynd 5. Mat íslenskra fjármálastjóra á óvissustigi í umhverfi í prósentum. 
Helstu óvissupættir í umhverfinu, að mati íslenskra fjármálastjóra, virðast vera próun á hráefnamörkuðum, hegðun og tilkoma keppinauta sem og fjárhagslegt umhverfi, próun í lagalegu umhverfi og neytendahegðun. Stærð fyrirtækja hefur marktæk áhrif á mat á óvissu m.t.t. tengsla fyrirtækja í atvinnugrein. Pví smærri sem fyrirtækin eru peim mun meiri óvissa er um tengsl milli fyrirtækja (p.e.a.s. eignarhald, tengsl stjórnenda o.p.h.). Petta á einnig við um hegðun birgja, pví smærri sem fyrirtækin eru - mælt í veltu og í starfsmannafjölda - peim mun meiri óvissa er um hegðun birgja.

Rannsóknin sem gerð var á fjármálastjórum í sænskum fyrirtækjum og vitnað var í fyrr í pessari grein gaf svipaða mynd af mati á óvissustigi umhverfis (Ekholm og Wallin, 2011). Íslenskir og sænskir fjármálastjórar eru sammála um að próun í samkeppni sé ófyrirsjáanlegur umhverfispáttur. Einnig eru peir nokkuð sammála um óvissustig í fjárhagslegu umhverfi og próun í hlítingu við lög og reglugerðir. Pað er pó munur á mati á alpjóðavæðingu og erlendri samkeppni sem er metin mun ófyrirsjáanlegri af sænsku fjármálastjórunum. Einnig virðast peir meta óvissu á hráefna- og aðfangamörkuðum sem mun meiri en íslenskir fjármálastjórar, pó svo að hjá báđum sé petta ófyrirsjáanlegasti pátturinn í umhverfi peirra.

Meginniðurstöður kafla 4.2 eru að pó svo að starfsumhverfi fjármálastjóra hafi tekið stakkaskiptum árið 2008 virðist mat íslenskra fjármálastjóra á ófyrirsjáanleika umhverfispátta 2014 ekki vera öðruvísi en t.d. mat sænskra fjármálastjóra. Einnig virðist mat peirra á hvaða pættir munu hafa áhrif á fjármáladeildina næstu árin hafa breyst mjög mikið síðan 2008.

\subsection{Breytingar á hlutverki og verkefnaáherslum fjármálastjóra og fjármáladeilda}

Íslensku fjármálastjórarnir voru spurðir hvaða áherslur væru í fjármáladeildum fyrirtækja peirra. Samanburður við rannsóknina árið 2008 er sýndur á mynd 6.

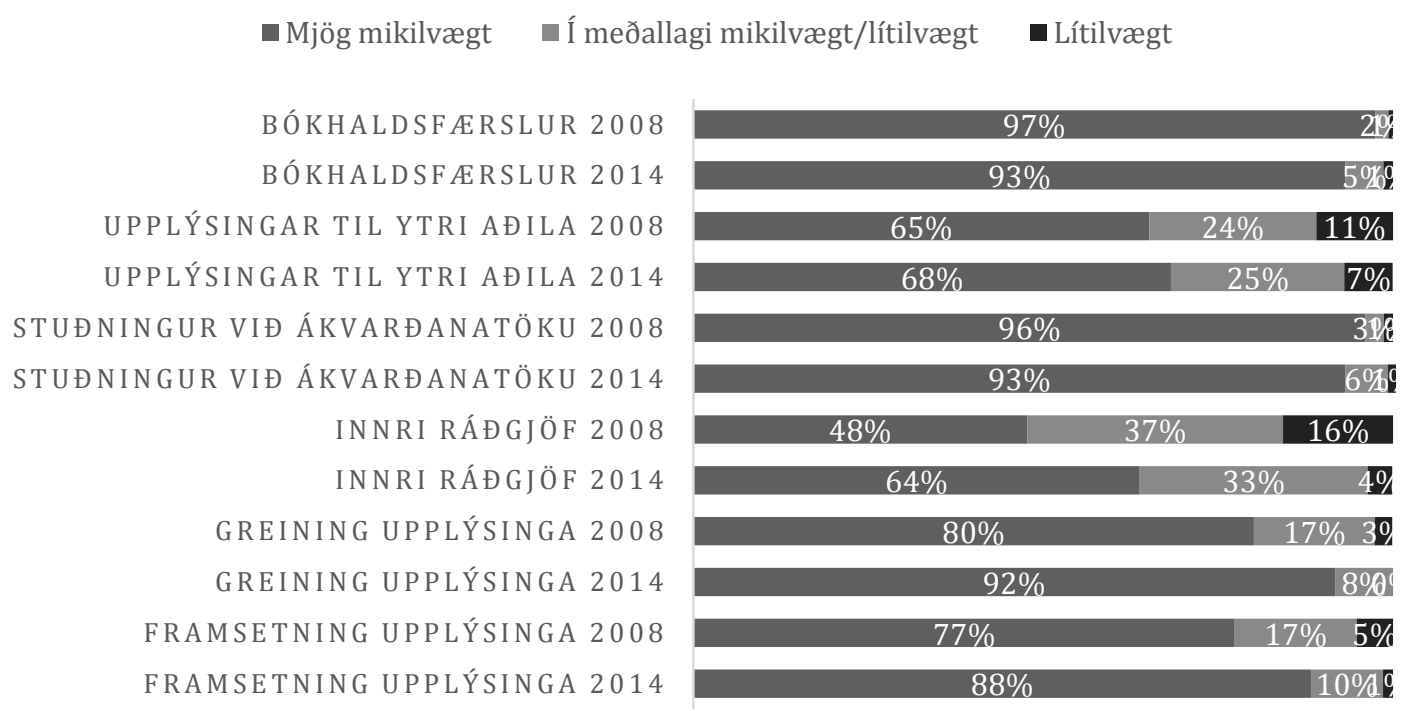

Mynd 6. Hlutverk fjármálastjóra 2008-2014.

Áhersla á bókhaldsfærslur og stuðningur við ákvarðanatöku er svo til hinn sami á milli ára. Pó má sjá vaxandi áherslu árið 2014 á greiningu upplýsinga og innri ráðgjöf, sem samsvarar pví sem erlendar rannsóknir sýna að er að gerast annarsstaðar og sem var lýst í 3. kafla hér að framan.

Íslensku fjármálastjórarnir voru spurðir um meginviðfangsefni sín í starfi tengd stjórnunarreikningsskilum. Mynd 7 sýnir svörin og breytingar milli áranna 2008 og 2014. Ekki er um að ræða miklar breytingar í áætlanagerð og kostnaðargreiningu en svo virðist sem 
árangursstjórnun sé gert hærra undir höfði í dag en fyrir 6 árum. Рað er að segja, áhersla á notkun árangursmælikvarða, viðmiðana (benchmarking) og skorkorta virðist fara vaxandi.

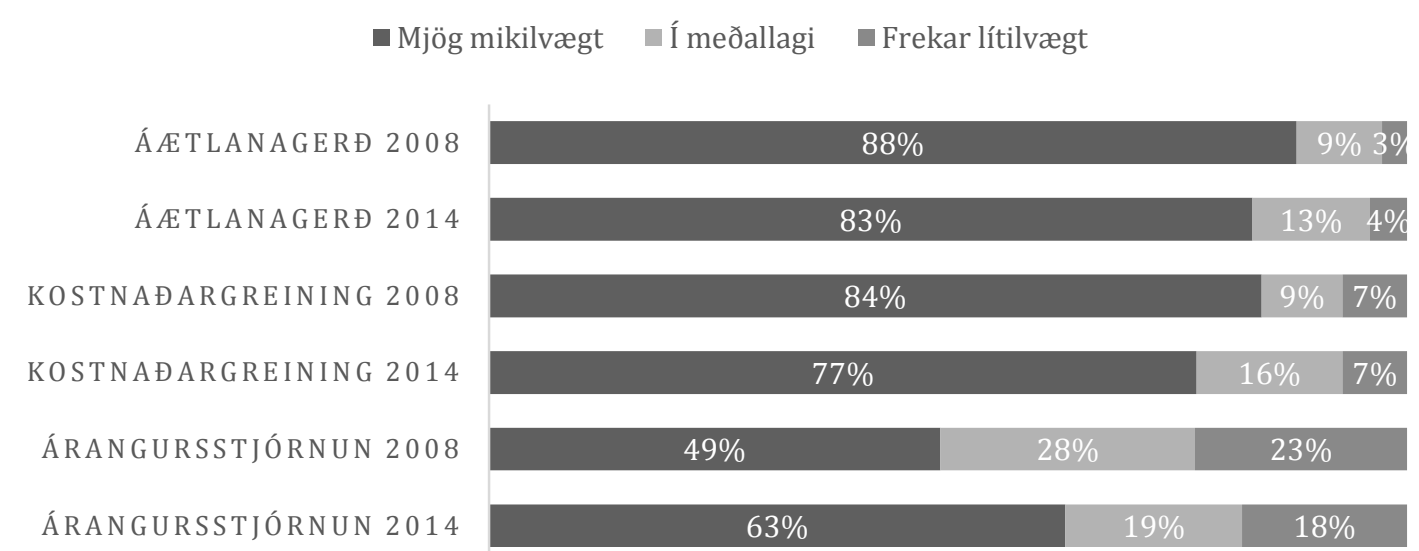

Mynd 7. Meginviðfangsefni fjármálastjóra í stjórnunarreikningsskilum árin 2008 og 2014.

Fjármálastjórarnir voru að lokum spurðir árið 2014 um hversu miklar eða litlar líkur peir teldu á pví að kerfinu yrði breytt á næstu árum (mynd 8). Frekar fáir telja miklar líkur á pví að stjórnunarreikningsskilakerfum fyrirtækisins verði breytt á næstu árum.

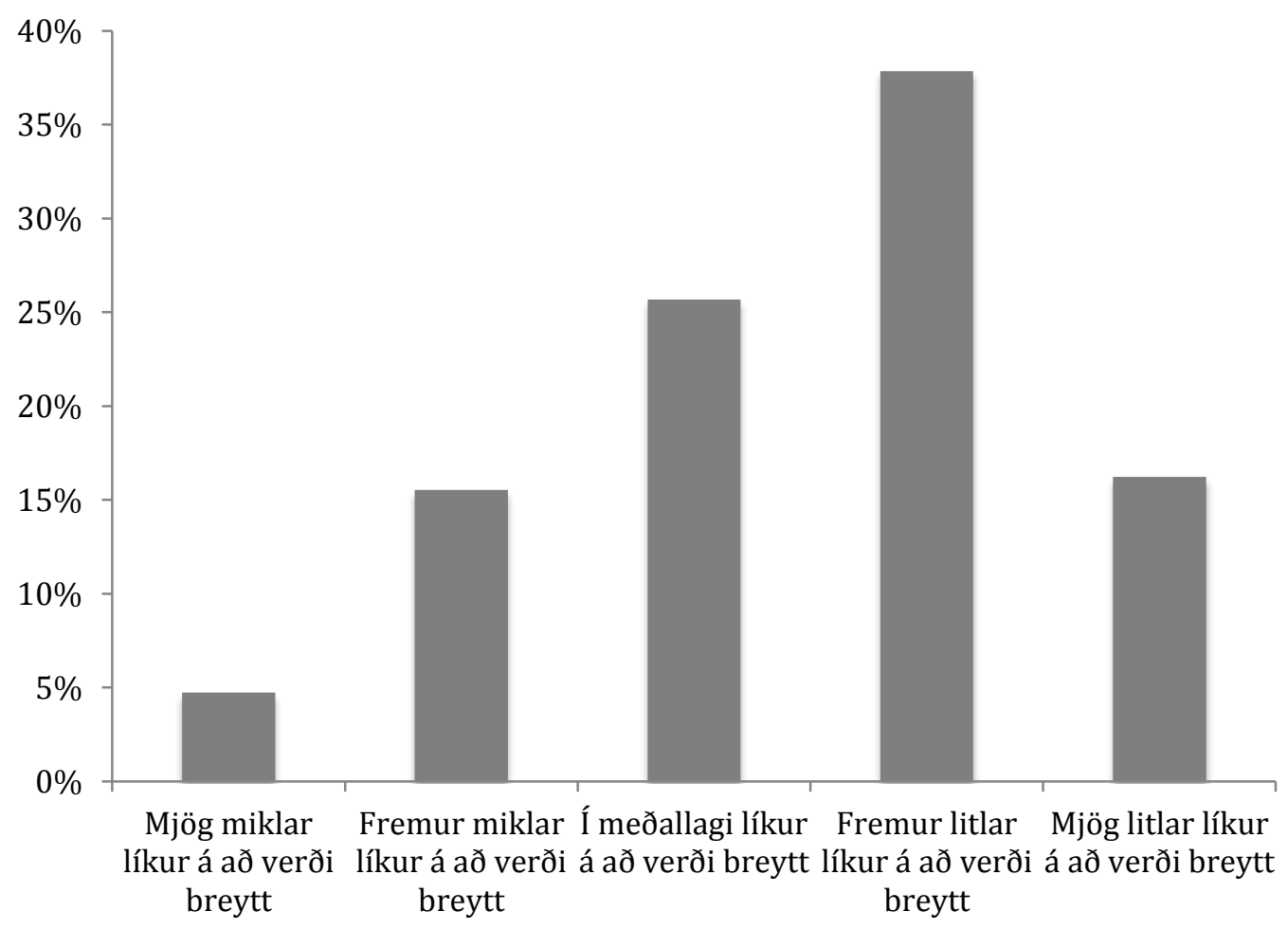

Mynd 8. Mat fjármálastjóra á líkum á breytingum á stjórnunarreikningsskilakerfum á næstu árum. 


\section{Lokaord}

Í upphafi pessarar greinar var priggja spurninga spurt:

1. Hvað einkennir fjármálastjóra í íslenskum fyrirtækjum?

2. Hvaða pættir í umhverfi fyrirtækja hafa mest áhrif á starf og hlutverk íslenskra fjármálastjóra?

3. Hafa orðið breytingar á áherslum og viðfangsefni stjórnunarreikningsskila íslenskra fjármálastjóra frá árinu 2008?

Niðurstöður rannsóknarinnar sýna að fjármálastjórar íslenskra fyrirtækja eru líklegri til að vera konur en fjármálastjórar í nágrannalöndunum. Раð er pví ekki hægt að tala um fjármálastjórastöðuna sem dæmigerða karlastöðu hér á landi eins og t.d. Ernst \& Young (2010) hafa lýst henni erlendis. Einnig virðast margir fjármálastjórar stærri íslenskra fyrirtækja vera tiltölulega nýir í starfi. Svo virðist sem hrunið 2008 hafi leitt til pó nokkurrar útskiptingar á fjármálastjórum stærri fyrirtækja, sem gæti bent til pess að pörf hafi verið á nýrri hæfni og áherslum eftir vaxtarárin fyrir 2008. Petta pýðir einnig að pað eru ekki nákvæmlega sömu fjármálastjórar í fyrirtækjum sem svöruðu ICEMAC 1 og ICEMAC 2-spurningunum.

Íslenskir fjármálastjórar pekkja til sömu aðferða stjórnunarreikningsskila og starfsbræður peirra í Danmörku og á Englandi (CIMA, 2009; Nielsen o.fl., 2003). Petta bendir til ákveðinnar stöðlunar í aðferðafræði og kennslu stjórnunarreikningsskila. Til dæmis eru aðgerðatengd kostnaðargreining, samfelldar spár og stefnumiðuð skortkort vel pekkt meðal íslenskra fjármálastjóra en pessar aðferðir hefur verið að finna í kennslubókum um stjórnunarreikningsskil í fjölda ára.

Fáir fjármálastjórar pekkja pó til hugsanaramma á sviði innra eftirlits á borð við COSO, COCO og COBIT. Pó er innra eftirlit, sem eitt af hlutverkum fjármálastjóra, metið mikilvægara 2014 en pað var gert 2008. Petta gæti gefið til kynna að íslenskir fjármálastjórar vinni eftir sínum eigin aðferðum pegar kemur að uppbyggingu innri eftirlitskerfa. Eða pá að t.d. COSOramminn sé notaður af endurskoðendum fyrirtækjanna við ráðleggingar um og mat á innra eftirliti án pess að pessi rammi sé beinlínis kynntur fyrir fjármálastjórum.

Раð er hægt að flokka breytingar í umhverfi íslenskra fjármálastjóra árið 2008 sem annaðhvort sudden shock eða avalanche eftir flokkunarkerfi Suarez og Olivia (2005). Hinsvegar virðist mat fjármálastjóra á óvissu í umhverfi fyrirtækja 2014 ekki vera mikið frábrugðið mati sænskra fjármálastjóra á óvissu í umhverfi peirra árið 2010 pegar Ekholm og Wallin (2011) gerðu sína rannsókn. Рað er að segja, íslenskir fjármálastjórar meta óvissu í umhverfi 2014 á svipuðu stigi og sænskir fjármálastjórar gerðu tveimur árum eftir að kreppan skall á.

Próun á hlutverki íslenskra fjármálastjóra virðist vera lík pví sem er erlendis. Рað er að segja, að fjármálastjórinn er ekki lengur bókari heldur inniber hlutverkið greiningu og miðlun upplýsinga og ráđgjöf til annarra stjórnenda. Eins og erlendar rannsóknir benda til er hlutverk fjármálastjórans að færast nær pví að vera „,business partner“ fremur en bókari (ACCA, 2012; Canace og Juras, 2014; CIMA, 2010). Svo virðist sem pessi próun sé líka að gerast í íslenskum fyrirtækjum.

Pað er áherslubreyting hjá fjármálastjórum milli áranna 2008 og 2014 pegar kemur að stjórnunarreikningsskilum. Áætlanagerð og kostnaðargreining hafa mest vægi sem stjórntæki eins og var fyrir árið 2008. Hins vegar virðist vera lögð mun meiri áhersla á árangursstjórnun árið 2014. Раð er að segja, notkun verkfæra eins og stefnukorts, skorkorts, mælikvarða og aðgerðamarkmiða. Samkvæmt peim kenningum sem ræddar voru í 3. kafla hafa erlendar 
rannsóknir tengt saman breytingar á starfsumhverfi, mat stjórnenda á óvissu og svo breytingar á notkun stjórnunarreikningsskilakerfa. Eftir að hafa rýnt í margar rannsóknir komst Chenhall (2006) t.d. að peirri niðurstöðu að aukin óvissa við miklar breytingar í starfsumhverfi leiði til aukinnar notkunar á sveigjanlegri (flexible) stjórntækjum sem stjórna árangri (performance) fremur en aðföngum (input) og aðgerðum (activities). Aukin áhersla íslenskra fjármálastjóra á pessi stjórntæki, samhliða klassískum stjórntækjum eins og áætlunum og kostnaðargreiningu, gæti bent til pessa.

Pó svo að hlutverk fjármálastjóra virðist vera að breytast í átt að meiri greiningu og stuðningi við ákvarðanatöku er pað áhugavert að ekki margir íslenskir fjármálastjórar telja líkur á pví að stjórnunarreikningsskilakerfum verði breytt innan næstu ára, prátt fyrir breytingar í starfsumhverfi peirra. Petta er áhugavert rannsóknarefni, pví pað gæti gefið til kynna að pað gæti skapast ósamræmi milli hlutverks fjármálastjóra og peirra kerfa sem peir nota til pess að gegna pessu hlutverki.

\section{Heimildir}

ACCA. (2012). The changing role of the CFO. The Association of Chartered Certified Accountants,. Sótt af http://www.accaglobal.com/us/en/research-insights/financetransformation/changing-CFO.html

Atkinson, A. A., Kaplan, R. S. og Young, S. M. (2011). Management Accounting (International Edition.). Upper Saddle River (NJ): Pearson Prentice Hall.

Boyden. (2014). The Changing Role of the Chief Financial Officer. Sótt 15. júlí 2014 af http://www.boyden.com/media/8234/44/the_changing_role_of_the/index.html

Burchell, S., Clubb, C., Hopwood, A., Hughes, J. og Nahapie, J. (1985). The Roles of Accounting in Organizations and Society. Accounting Organizations and Society, 5, 5-27.

Canace, T. G. og Juras, P. (2014). CFO: From Analyst to Catalyst. Strategic Finance, 96(2), 27-33.

CCD. (2009). The 2008 Nordic 500. Oslo: Center for Corporate Diversity. Sótt af http://www.corporatediversity.no/

Chenhall, R. (2003). Management Control Systems Design Within its Organisational Context: Findings from Contingency-based research and Directions for the Future. Accounting, Organizations and Society, Vol. 28, 127-168.

Chenhall, R. (2006). Theorizing Contingencies in Management Control Systems Research. Í A. G. H. Christopher S. Chapman og D. S. Michael (ritstj.), Handbooks of Management Accounting Research (Volume 1. bindi, bls. 163-205). Elsevier.

CIMA. (2009). Management Accounting Tools for Today and Tomorrow. London: Chartered Institute of Management Accountants. Sótt af http://www.cimaglobal.com/Documents/Thought_leadership_docs/CIMA\%20Tools\%20 and\%20Techniques\%2030-11-09\%20PDF.pdf

CIMA. (2010). CFO to CEO: Why Roles and Rules are Changing. Insight - The e-magazine for Accountants. Sótt af http://www.cimaglobal.com/Thoughtleadership/Newsletters/Insight-e-magazine/Insight-2010/Insight-November-2010/CFOto-CEO-why-roles-and-rules-are-changing/

Davenport, T. (2010). BI and organizational decisions. International Journal of Business Intelligence Research, 1, 1-12.

Deloitte. (2011). Women in the Boardroom. Sótt 1. ágúst 2014 af www.global.corpgov.deloitte.com 
Edwards, R. og Broyns, T. (2013). A History of Management Accounting: The British Experience. New York: Routledge.

Ekholm, B.-G. og Wallin, J. (2011). The Impact of Uncertainty and Strategy on the Perceived Usefulness of Fixed and Flexible Budgets. Journal of Business Finance \& Accounting, 38, 145164.

Ernst \& Young. (2010). The DNA of the CFO. Sótt 22. september 2014 af http://www.ey.com/Publication/vwLUAssets/The-DNA-of-the-CFO-2010/\$FILE/TheDNA-of-the-CFO-2010.pdf

European Commission. (2005). The new SME definition: user guide and model declaration. [Luxembourg: Office for Official Publications of the European Communities.

Ewert, R. og Wagenhofer, A. (2007). Management Accounting Theory and Practice in the German-Speaking Countries. Í C. Chapman, A. Hopwood og M. Shields (ritstj.), Handbook of Management Accounting Research (bls. 1035-1069). Oxford: Elsevier.

Fleischman, R. og Tyson, T. (2007). The History of Management Accounting in the US. Í C. Chapman, A. G. Hopwood og M. D. Shields (ritstj.), Handbook of Management Accounting Research (1.-2. bindi, 2. bindi, bls. 1071-1089). Oxford: Oxford University Press.

Frier, S. og Hymowitz, C. (2013, 6. febrúar). Women CFOs Reach Record Level in U.S. as Top Job Remains Elusive. Bloomberg. Sótt 21. júlí 2014 af http://www.bloomberg.com/news/2013-02-06/women-cfos-reach-record-level-in-u-s-astop-job-remains-elusive.html

Garengo, P. og Bititci, U. (2007). Towards a contingency approach to performance measurement: an empirical study in Scottish SMEs. International Journal of Operations $\mathcal{E}$ Production Management, 27(8), 802-825.

Grabner, I. og Moers, F. (2013). Management control as a system or a package? Conceptual and empirical issues. Accounting, Organizations \& Society, 38(6/7), 407-419.

Granlund, M. og Lukka, K. (1998). It's a small world of management accounting practices. Journal of Management Accounting Research, 10, 153-179.

Gylfi Dalmann Aðalsteinsson og Póra Hrólfsdóttir. (2008). Útdrættir meistararitgerða i viðskiptafræði. HÍ. $\quad$ Sótt 8 8 $\quad$ september 2014 af http://english.hi.is/files/skjol/_ttir_meistararitger_a___vi__skiptafr___i.pdf

Hagstofa Íslands. (e.d.). Ársbreyting landsframleiðslu 1980-2013. Hagstofa Íslands. Sótt 22. september 2014

http://hagstofa.is/?PageID=2602\&src=https://rannsokn.hagstofa.is/pxis/Dialog/varval.asp ?ma=THJ01702\%26ti=\%C1rsbreyting+landsframlei\%F0slu+1980\%2D2013\%26path=../Dat abase/thjodhagsreikningar/landsframleidsla_althj/\%26lang=3\%26units=Hlutfall

Heimur - Frjáls Verslun. (2014). Frjáls Verslun webpage. Sótt 9. september 2014 af http://www.heimur.is/heimur/timarit/frjals_verslun/

Hoque, Z. (2004). A contingency model of the association between strategy, environmental uncertainty and performance measurement: impact on organizational performance. International Business Review, 13(4), 485-502.

Icelandic Chamber of Commerce. (2014). The Icelandic Economy: Current State, Recent Developments and Future Outlook. Sótt 9. september 2014 af http://vi.is/\%C3\%BAtg\%C3\%A1fa/sk\%C3\%BDrslur/2014_07_18_the_icelandic_economy. pdf

IFAC. (2013). Role of the CFO. International Federation of Accountants. Sótt 3. ágúst 2014 af https://www.ifac.org/publications-resources/role-and-expectations-cfo-global-debatepreparing-accountants-finance-leaders 
Kimmel, P., Weygandt, J. og Kieso, D. (2011). Financial Accounting. London: Wiley.

Malmi, T. og Brown, D. A. (2008). Management control systems as a package-Opportunities, challenges and research directions. Management Accounting Research, 19(4), 287-300.

Näsi, S. og Rohde, C. (2007). Development of Cost and Management Accounting Ideas in the Nordic Countries. Í C. Chapman, A. G. Hopwood og M. D. Shields (ritstj.), Handbook of Management Accounting Research (1.-2. bindi, 2. bindi, bls. 1091-1118). Oxford: Elsevier.

Nielsen, S., Melander, P. og Jacobsen, M. (2003). Undersøgelse af Moderne Økonomistyringsværktøjer i Danmark 2001 (Working Paper). Aarhus (Denmark): Aarhus School of Business. Sótt af http://econpapers.repec.org/paper/hhbaaracc/03-015.htm

Rikhardsson, P. (2013). Business Intelligence i Danmark. Copenhagen: Herbert Nathan \& Co. Sótt af www.herbertnathan.com

Rikhardsson, P., Karlsson, T., Sigurjonsdottir, T. og Hilmarsson, S. (2012). Rear-view mirror navigation: pre-crisis management accounting and control practices in Iceland. International Journal of Managerial and Financial Accounting, 4(4), 402-422.

Rikhardsson, P. og Kraemmergaard, P. (2006). Identifying the impacts of enterprise system implementation and use: Examples from Denmark. International Journal of Accounting Information Systems, 7, 36-49.

Stede, W. Van der. (2011). Management Accounting Research in the Wake of the Crisis: Some Reflections. European Accounting Review, 20(4), 605-623.

Tarantino. (2011). Financial Internal Controls Best Practices. London: Wiley. 


\section{Viðauki}

Spurningar í ICEMAC 1 og ICEMAC 2 sem niðurstöđur pessarar greinar byggjast á.

Hversu fyrirsjáanlegir eða ófyrirsjáanlegir eru eftirfarandi pættir í starfsumhverfi fyrirtækisins?

\begin{tabular}{|c|c|c|c|c|c|}
\hline & $\begin{array}{c}\text { Mjög } \\
\text { fyrirsjáanleg } \\
t\end{array}$ & $\begin{array}{c}\text { Frekar } \\
\text { fyrirsjáanleg } \\
\mathbf{t}\end{array}$ & $\begin{array}{c}\text { Í } \\
\text { meðallag } \\
\text { i } \\
\end{array}$ & $\begin{array}{c}\text { Frekar } \\
\text { ófyrirsjáanleg } \\
t\end{array}$ & $\begin{array}{c}\text { Mjög } \\
\text { ófyrirsjáanleg } \\
\mathbf{t}\end{array}$ \\
\hline Hegðun birgja & () & ( ) & () & () & () \\
\hline $\begin{array}{l}\text { Eftirspurn, } \\
\text { neytendahegðun }\end{array}$ & ( ) & () & () & () & () \\
\hline $\begin{array}{l}\text { Alpjóðavæðing og } \\
\text { erlend samkeppni }\end{array}$ & ( ) & ( ) & ( ) & ( ) & ( ) \\
\hline $\begin{array}{l}\text { Hegðun } \\
\text { keppinauta }\end{array}$ & ( ) & ( ) & ( ) & ( ) & ( ) \\
\hline $\begin{array}{l}\text { Tæknilegar } \\
\text { breytingar }\end{array}$ & ( ) & ( ) & ( ) & ( ) & ( ) \\
\hline $\begin{array}{l}\text { Lög og reglugerðir } \\
\text { sem fyrirtækið } \\
\text { verður að hlíta }\end{array}$ & ( ) & ( ) & ( ) & ( ) & ( ) \\
\hline $\begin{array}{l}\text { Fjárhagslegt } \\
\text { umhverfi }\end{array}$ & ( ) & ( ) & ( ) & ( ) & ( ) \\
\hline $\begin{array}{l}\text { Tengsl milli } \\
\text { fyrirtækja í } \\
\text { atvinnugreininni }\end{array}$ & ( ) & ( ) & ( ) & ( ) & ( ) \\
\hline $\begin{array}{l}\text { Nýjar vörur frá } \\
\text { keppinautum }\end{array}$ & ( ) & ( ) & ( ) & ( ) & ( ) \\
\hline Nýir keppinautar & () & () & () & () & () \\
\hline $\begin{array}{l}\text { Próun á } \\
\text { hráefnamörkuðu } \\
\text { m }\end{array}$ & ( ) & ( ) & ( ) & () & () \\
\hline $\begin{array}{l}\text { Próun á } \\
\text { atvinnumarkaði }\end{array}$ & $($ ) & ( ) & ( ) & ( ) & ( ) \\
\hline
\end{tabular}


Hversu mikil eða lítil áhrif telur pú að eftirtaldir pættir muni hafa á starfsemi fyrirtækisins í framtíðinni?

\begin{tabular}{|c|c|c|c|c|c|}
\hline & $\begin{array}{l}\text { Mjög mikil } \\
\text { áhrif }\end{array}$ & $\begin{array}{c}\text { Frekar } \\
\text { mikil áhrif }\end{array}$ & $\begin{array}{c}\text { Í meðallagi } \\
\text { mikil/lítil } \\
\text { áhrif } \\
\end{array}$ & $\begin{array}{l}\text { Frekar lítil } \\
\text { áhrif }\end{array}$ & $\begin{array}{l}\text { Mjög lítil } \\
\text { áhrif }\end{array}$ \\
\hline $\begin{array}{l}\text { Próun í } \\
\text { upplýsingatækni }\end{array}$ & ( ) & ( ) & () & ( ) & ( ) \\
\hline $\begin{array}{l}\text { Framhaldsmenntun } \\
\text { starfsmanna }\end{array}$ & ( ) & ( ) & ( ) & ( ) & ( ) \\
\hline Alpjóðavæðing & () & () & ( ) & () & ( ) \\
\hline Flækjustig rekstrarins & () & () & () & () & () \\
\hline $\begin{array}{l}\text { Alpjóðlegir } \\
\text { reikningsskilastaðlar } \\
\text { (IFRS) }\end{array}$ & ( ) & ( ) & ( ) & ( ) & ( ) \\
\hline $\begin{array}{l}\text { Próun í lögum um } \\
\text { ársreikninga }\end{array}$ & ( ) & ( ) & ( ) & ( ) & ( ) \\
\hline
\end{tabular}

Hversu mikið eða lítið vægi hafa eftirtaldir pættir innan fjármáladeildar?

\begin{tabular}{|c|c|c|c|c|c|}
\hline & $\begin{array}{c}\text { Mjög } \\
\text { mikið vægi }\end{array}$ & $\begin{array}{c}\text { Frekar } \\
\text { mikið vægi }\end{array}$ & $\begin{array}{l}\text { Í meðallagi } \\
\text { mikið/lítið } \\
\text { vægi }\end{array}$ & $\begin{array}{l}\text { Frekar lítið } \\
\text { vægi }\end{array}$ & $\begin{array}{l}\text { Mjög lítið } \\
\text { vægi }\end{array}$ \\
\hline Bókhaldsfærslur & () & () & () & () & () \\
\hline $\begin{array}{l}\text { Upplýsingagjöf til ytri } \\
\text { aðila }\end{array}$ & ( ) & ( ) & ( ) & ( ) & ( ) \\
\hline $\begin{array}{l}\text { Stuðningur við } \\
\text { ákvarðanatöku } \\
\text { stjórnenda }\end{array}$ & ( ) & ( ) & ( ) & ( ) & ( ) \\
\hline Innri ráðgjöf & () & () & () & () & () \\
\hline Greining upplýsinga & ( ) & $($ ) & ( ) & $($ ) & () \\
\hline $\begin{array}{l}\text { Framsetning } \\
\text { upplýsinga }\end{array}$ & ( ) & ( ) & ( ) & ( ) & ( ) \\
\hline Innra eftirlit & $($ ) & () & $($ ) & () & () \\
\hline Áhættumat & $($ ) & $($ ) & $($ ) & $($ ) & $($ ) \\
\hline Annad & () & () & () & () & () \\
\hline
\end{tabular}


Hversu mikill eða lítill áhugi er fyrir að taka upp eftirtaldar aðferðir í fyrirtækinu?

\begin{tabular}{|c|c|c|c|c|c|c|}
\hline & $\begin{array}{c}\text { Aðferðin } \\
\text { er pegar } \\
\text { notuð }\end{array}$ & $\begin{array}{c}\text { Pað er } \\
\text { áhugi fyrir } \\
\text { pví að taka } \\
\text { upp } \\
\text { aðferðina }\end{array}$ & $\begin{array}{c}\text { Í meðallagi } \\
\text { mikill/ lítill } \\
\text { áhugi fyrir } \\
\text { pví að taka } \\
\text { upp } \\
\text { aðferðina }\end{array}$ & $\begin{array}{c}\text { Pað er } \\
\text { ekki áhugi } \\
\text { fyrir pví } \\
\text { að taka } \\
\text { upp } \\
\text { aðferðina }\end{array}$ & $\begin{array}{l}\text { Aðferðin } \\
\text { hefur } \\
\text { verið } \\
\text { reynd og } \\
\text { er ekki } \\
\text { lengur í } \\
\text { notkun }\end{array}$ & $\begin{array}{c}\text { Pekki } \\
\text { ekki } \\
\text { aðferðina }\end{array}$ \\
\hline $\begin{array}{l}\text { Activity based } \\
\text { budgeting }\end{array}$ & ( ) & ( ) & ( ) & ( ) & () & ( ) \\
\hline $\begin{array}{l}\text { Activity based } \\
\text { costing }\end{array}$ & () & ( ) & ( ) & ( ) & () & () \\
\hline $\begin{array}{l}\text { Balanced } \\
\text { scorecard }\end{array}$ & ( ) & ( ) & ( ) & () & () & ( ) \\
\hline $\begin{array}{l}\text { Beyond } \\
\text { budgeting }\end{array}$ & ( ) & ( ) & ( ) & () & () & ( ) \\
\hline $\begin{array}{l}\text { Business } \\
\text { Excellence }\end{array}$ & () & ( ) & ( ) & () & ( ) & () \\
\hline COBIT & ( ) & $($ ) & ( ) & ( ) & $($ ) & $($ ) \\
\hline COCO & ( ) & ( ) & ( ) & ( ) & ( ) & ( ) \\
\hline COSO & () & () & () & () & () & () \\
\hline $\begin{array}{l}\text { Framlegðar } \\
\text { greining }\end{array}$ & () & () & () & () & () & () \\
\hline $\begin{array}{l}\text { Full cost } \\
\text { accounting }\end{array}$ & () & ( ) & ( ) & () & () & ( ) \\
\hline ISO 27000 & () & () & () & () & ( ) & () \\
\hline Kaizen costing & $($ ) & ( ) & $($ ) & $($ ) & ( ) & $($ ) \\
\hline Lean & ( ) & ( ) & ( ) & ( ) & ( ) & ( ) \\
\hline $\begin{array}{l}\text { Lifecycle } \\
\text { costing }\end{array}$ & () & () & () & () & () & () \\
\hline $\begin{array}{l}\begin{array}{l}\text { Policy } \\
\text { deployment }\end{array} \\
\end{array}$ & ( ) & ( ) & ( ) & () & () & $($ ) \\
\hline $\begin{array}{l}\text { Samfelld spá } \\
\text { (Rolling } \\
\text { forecasts) }\end{array}$ & () & () & ( ) & () & () & () \\
\hline Six sigma & $($ ) & () & () & $($ ) & $($ ) & () \\
\hline $\begin{array}{l}\text { Spálíkön } \\
\text { (Forecasting) }\end{array}$ & () & () & () & () & () & () \\
\hline Strategy maps & ( ) & ( ) & ( ) & ( ) & ( ) & () \\
\hline Target costing & () & ( ) & () & () & () & () \\
\hline
\end{tabular}


Hvað er síðasta prófgráðan pín?

Hve lengi hefur pú verið í núverandi stöðu?
( ) $<1$ ár
( ) 1 - 2 ár
( ) 2 - 5 ár
( ) 5 - 10 ár
( ) > 10 ára

Hve lengi hefur pú starfað í fyrirtækinu?

( ) $<1$ ár

( ) 1 - 2 ár

( ) 2 - 5 ár

( ) 5 - 10 ár

( ) >10 ára

Hversu ánægð(ur) eða óánægð(ur) ertu almennt með stjórnunarreikningsskilaaðferðir (management accounting) í fyrirtæki pínu?
( ) Mjög ánægð(ur)
( ) Fremur ánægð(ur)
( ) Í meðallagi ánægð(ur)/óánægð(ur)
( ) Fremur óánægð(ur)
( ) Mjög óánægð(ur)

Hversu miklar eða litlar líkur eru á pví að stjórnunarreikningsskilaaðferðir (management accounting) i fyrirtæki pínu verði að mestu óbreyttar næstu 1-2 árin?
( ) Mjög miklar
( ) Fremur miklar
( ) Í meðallagi miklar/litlar
( ) Fremur litlar
( ) Mjög litlar 